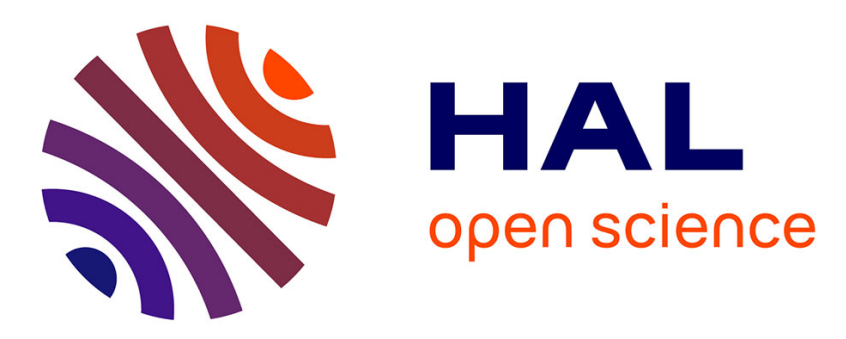

\title{
Photopyroelectric detection of hydrogen/oxygen mixtures
}

\author{
C. Christofides, A. Mandelis
}

\section{To cite this version:}

C. Christofides, A. Mandelis. Photopyroelectric detection of hydrogen/oxygen mixtures. Journal de Physique IV Proceedings, 1994, 04 (C7), pp.C7-511-C7-513. 10.1051/jp4:19947120 . jpa-00253174

\section{HAL Id: jpa-00253174 https://hal.science/jpa-00253174}

Submitted on 1 Jan 1994

HAL is a multi-disciplinary open access archive for the deposit and dissemination of scientific research documents, whether they are published or not. The documents may come from teaching and research institutions in France or abroad, or from public or private research centers.
L'archive ouverte pluridisciplinaire HAL, est destinée au dépôt et à la diffusion de documents scientifiques de niveau recherche, publiés ou non, émanant des établissements d'enseignement et de recherche français ou étrangers, des laboratoires publics ou privés. 


\title{
Photopyroelectric detection of hydrogen/oxygen mixtures
}

\author{
C. Christofides and A. Mandelis
}

Photothermal and Optoelectronic Diagnostics Laboratory, Department of Mechanical Engineering and Center for Hydrogen and Electrochemical Studies (CHES), University of Toronto, Toronto, Canada, MSS IA4

It has been found that the photopyroelectric (PPE) sensor made of thin film polyvinylidene fluoride (PVDF), sputter-coated with palladium, can detect trace hydrogen gas in the presence of pure oxygen without significant drift and stabilization problems. Presently, hydrogen concentration as low as $0.1 \%$ in flowing $99.9 \%$ oxygen has been detected under STP conditions. The detector has been used without a reference sensor (single-ended mode) which simplifies the sensor system compared to previous work.

\section{INTRODUCTION}

Sometime ago, in our laboratory, we undertook the task of developing and optimizing a fast, sensitive, and inexpensive photopyroelectric (PPE) sensor for trace hydrogen gas detection at room temperature [1-6]. During that time the base objective was to discover and prove the hydrogen sensing ability of the new device under ideal experimental conditions such as: (a) clean palladium surfaces; (b) room temperature; and (c) the minimization of any environmental impurities, in order to detect hydrogen in nitrogen ambient [1,2]. In 1990 in an extensive review paper a critical comparison between the new PPE hydrogen sensor and other conventional devices was presented [7]. Significant progress has been made both in the development and in the optimization of the new device [8], as well as towards the understanding of the relevant physical mechanisms [9]. The PPE detector was found capable of operating within a broad range of temperatures $\left(+53\right.$ to $\left.-60^{\circ} \mathrm{C}\right)$ with good prospects down to that of liquid nitrogen $[8-10]$. Broader interest in this photothermal device has been shown and different versions of our PPE sensor were already constructed and used [11].

Recently, hydrogen detection was studied under simulated ambient air conditions. This paper describes new results concerning PPE hydrogen sensor used for detection of various hydrogen concentration in oxygen.

\section{EXPERIMENTAL APPARATUS}

An experimental system that allowed us to test the response of the Pd-PVDF photopyrolectric sensor to flows of hydrogen, oxygen, nitrogen, and hydrogen/oxygen mixtures, with hydrogen concentrations ranging from $1000 \mathrm{ppm}$ to pure hydrogen has been constructed. The system consists of four parts; gas control; external temperature control, and test cell (internal) temperature control; fiber optic and laser system; and 
finally signal generation and analysis as shown in Fig. 1. Three different types of signals have been monitored:

$$
S_{A}=\frac{A}{R} \quad \Delta S_{R}=\frac{A-B}{R} \quad \text { and } \quad \Delta S_{B}=\frac{A-B}{B}
$$

where $A$ and $B$ are the signals obtained by the active and reference detector, respectively, and $R$ is the a.c. laser power reference output obtained from a photodiode. More details on the signal generation and analysis are given in previous reports $[1,2]$.

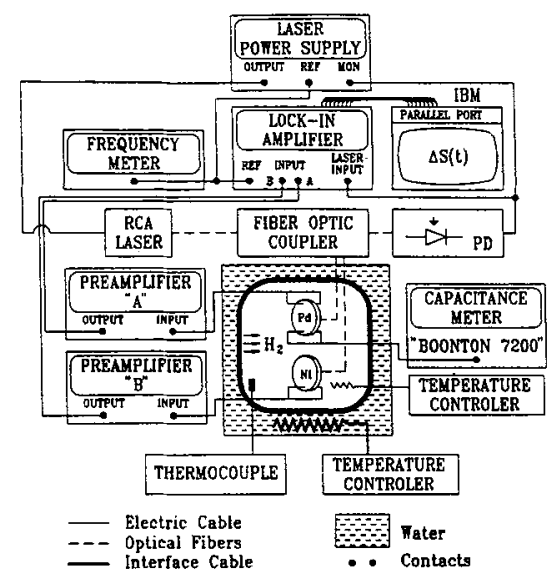

Fig. 1 Schematic diagram of PPE gas sensor set-up.

\section{DETECTION OF HYDROGEN/OXYGEN MIXTURES}

Figure 2 shows a typical PPE response as a function of time. Before each experiment the detector was cleaned for 30 minutes with pure oxygen. Then hydrogen $(500 \mathrm{ml} / \mathrm{min})$ at the prescribed flow rate was admitted to the test cell. Similar results were obtained through cycling with other $\left[\mathrm{H}_{2}\right] /\left[\mathrm{O}_{2}\right]$ ratios. In Fig. 2 it is seen that after the interruption of $\mathrm{H}_{2}$ and introduction of pure oxygen, there appears an intermediate signal "induction" period before the signal reaches the saturation level(s). At low $\left[\mathrm{H}_{2}\right]$ concentrations in hydrogen/oxygen mixtures, the presence of this induction period is not well pronounced. It is probable that this signal saturation delay observed in the case of high concentrations of hydrogen in oxygen is due to the production of water on the $P d$ surface. If so, there is no evidence of cumulative surface water effect on the reversibility of the signals. Another possibility for the observed induction period might be the phase transition of $P d$ (from $\alpha$ to $\beta$ ) form in the presence of hydrogen in the bulk. This effect, however, is known to occur at lower hydrogen concentrations $(\leq 2000 \mathrm{ppm})[12]$ and has not been observed with the photopyroelectric sensor in $\mathrm{H}_{2} / \mathrm{N}_{2}$ mixtures in the concentration range of $0.1-100 \%$ [2]. Fig. 3 shows the variation of the saturated photopyroelectric signal, $\Delta S_{s}=\left(S_{A}\right)_{s}$ as a function of hydrogen concentration. Note that $\Delta S_{S}$ increases monotonically when hydrogen concentration increases, while the signal associated with the lowest $(0.1 \%)$ hydrogen concentration is not believed to be an absolute minimum. Differential signal detection is expected to improve this sensitivity limit.

The Pd-PPE sensor shows excellent reproducibility of the PPE saturated signal $\Delta S_{S}$ after many cycles of exposure to hydrogen $([\mathrm{H}]=50 \%)$ at room temperature and opens the way for photopyroelectric measurements under real, rather than simulated ambient conditions. The sensitivity of $1000 \mathrm{ppm}$ in $\mathrm{O}_{2}$ under simulated dynamic flow-through ambient air conditions is a very promising step toward the establishment of a continuously monitoring $\mathrm{H}_{2}$ sensor operating at room temperature and atmospheric 
conditions including the outdoors. The experiments performed under several hours and duty cycles prove that such a device could serve as a valuable, real-time detector of hydrogen. Signal stability improves in time following the system turn on.

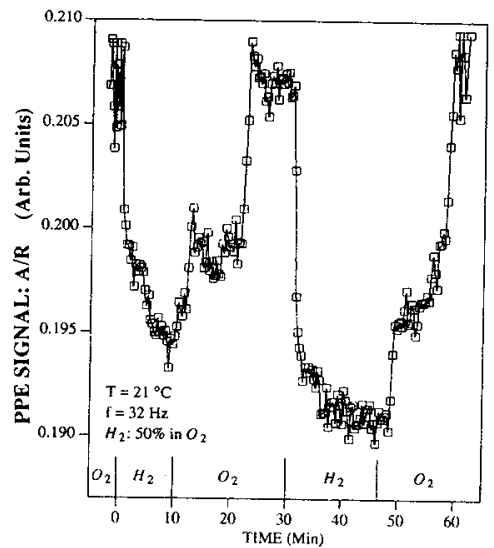

Fig. 2 Photopyroelectric signal ratio $(A / R)$ as a function of time for gaseous mixture containing 50\% hydrogen in oxygen.

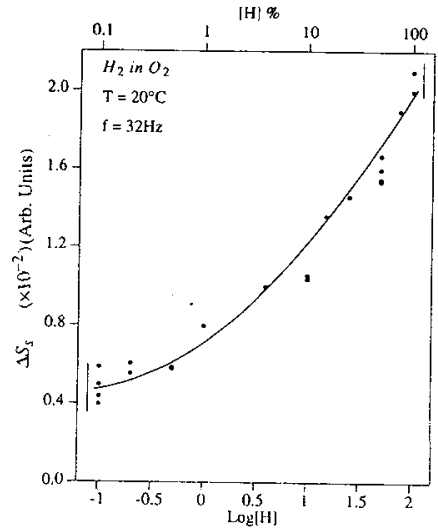

Fig. 3 Photopyroelectric saturated signal $\left(\Delta S_{s}\right)$ as a function of hydrogen concentration $[\mathrm{H}]$. The solid lines represent error at low and at high concentrations.

\section{REFERENCES}

[1] Mandelis, A. and Christofides, C., Sensors and Actuators B2 (1990) 79.

[2] Christofides, C. and Mandelis, A., J. Appl. Phys. 66 (1990) 3975.

[3] Christofides, C. and Mandelis, A., (IEEE 1989 Ultrasonics Symp., Montreal, Quebec, Canada Oct. 1989) Vol. 1613.

[4] Mandelis, A. and Christofides, C., in 6th Int. Topical Meeting on Photoacoustic and Photothermal Phenomena II, Baltimore, MD, USA, August (1989). Springer Series in Optical Sciences Vol. 62 (1989) 347.

[5] Mandelis, A. and Christofides, C., J. Vac. Sci. \& Technol. A8 (1990) 3980.

[6] Christofides, C. and Mandelis, A., Int. J. Hyd. Energy 16 (1991) 557.

[7] Christofides, C. and Mandelis, A., J. Appl. Phys. 66 (1990) R1-R33.

[8] Christofides, C., Mandelis, A. and Enright, J. ,Jpn. J. Appl. Phys. 30 (1991) 2916.

[9] Mandelis, A. and Christofides, C., J. Appl. Phys., 70 (1991) 4496.

[10] Mandelis, A. and Christofides, C., "Photoacoustic and Photothermal Phenomena III", D. Bicanic (Ed.), Springer Series in Optical Sciences Vol. 69 (1992) 6.

[11] Balasubramanian, A., Santiago-Aviles, J.J. and Zemel, J.N., J. Appl. Phys. 69 (1991) 1102.

[12] Lewis, F.A., The Palladium/Hydrogen System (Academic Press, New York, 1967). 